\title{
PALEOCEANOGRAPHIC CURRENTS
}

PALEOCEANOGRAPHY, VOL. 8, NO. 6, PAGES 691-697, DECEMBER 1993

\section{THERMODYNAMIC INFLUENCES ON THE MARINE CARBON ISOTOPE RECORD}

Christopher D. Charles

Scripps Institution of Oceanography, University of California, San Diego, La Jolla

James D. Wright and Richard G. Fairbanks Lamont-Doherty Earth Observatory of Columbia University, Palisades, New York

\begin{abstract}
Air-sea exchange represents an important controlling factor for the distribution of carbon isotopes in the modern ocean, even below the surface mixed layer. Here we show that this thermodynamic influence varies between water masses with a magnitude which is large relative to the amplitude of typical deep sea sediment $\delta^{13} \mathrm{C}$ records. Thus, changes in air-sea exchange processes must be regarded as a significant source of variability for any marine $\delta^{13} \mathrm{C}$ signal.
\end{abstract}

\section{INTRODUCTION}

Paleoceanographers commonly take the $\delta^{13} \mathrm{C}$ of fossil foraminifera as a direct proxy for nutrient concentrations, an approach which has provided considerable insight to the past oceanic chemistry and circulation. For example, the mapping of glacial-age $\delta^{13} \mathrm{C}$ values led to the realization that the production of North Atlantic Deep Water (NADW) was substantially different during the last glacial period [e.g. Boyle and Keigwin, 1985; Mix and Fairbanks, 1985; Duplessy et al., 1988; Oppo and Fairbanks, 1987]. However, with the increasing demand for precise testing of carbon cycle models, it has become necessary to recognize the nonbiological influences on the oceanic $\delta^{13} \mathrm{C}$ signal. In particular, the capacity of the ocean's inorganic carbon pool to exchange

\section{Copyright 1993}

by the American Geophysical Union.

Paper number 93PA01803. 0883-8305/93/93PA-01803\$10.00 isotopically with the atmosphere creates the potential for significant $\delta^{13} \mathrm{C}$ variability which deviates from the basic trend established through biological fractionation. In some areas of the surface ocean today, air-sea exchange completely masks the relationship between $\delta^{13} \mathrm{C}$ and nutrients [Broecker and Peng, 1982; Broecker and Maier-Reimer, 1992; Charles and Fairbanks, 1990]. Surface waters having experienced varying degrees of isotopic equilibration with the atmosphere are subsequently incorporated in deep and intermediate water, and thus different thermodynamic influences are mixed throughout the ocean.

The need for a fuller understanding of these equilibration processes is underscored by the development of other nutrient tracers such as $\mathrm{Cd}$ [Boyle, 1988a] and Ba [Lea and Boyle, 1990] in foraminifera and $\mathrm{Ge}$ in diatoms [Froelich et al., 1989]. In many cases, these tracers differ dramatically from $\delta^{13} \mathrm{C}$ in the deep sea sediment record, and air-sea exchange rep-resents one principle mechanism for decoupling the tracers. Furthermore, interpretation of the recently established atmospheric $\delta^{13} \mathrm{C}$ record spanning the last 20 kyr [Marino et al., 1992; Leuenberger et al., 1992] depends critically on the extent and conditions of air-sea isotopic exchange.

The purpose of this paper is to delineate the geographic influence of air-sea exchange on $\delta^{13} \mathrm{C}$ in the modern ocean, while discussing the possible ramifications for paleoceanographic interpretations based on $\delta^{13} \mathrm{C}$ in foraminifera. For Quaternary $\delta^{13} \mathrm{C}$ records, gas exchange effects should be most prominent in upper layer water masses. However, over longer (Cenozoic) times, different water mass formation processes could result in different thermodynamic signatures in the deep ocean as well. 


\section{GAS EXCHANGE EFFECT}

Given sufficient time for isotopic equilibration to occur, air-sea exchange of $\mathrm{CO}_{2}$ leaves surface waters enriched in ${ }^{13} \mathrm{C}$ relative to mean ocean water, and conversely, atmospheric $\mathrm{CO}_{2}$ is left relatively depleted. In addition, isotopic fractionation upon gas exchange increases with decreasing temperatures. Seawater completely equilibrated with the atmosphere at $0^{\circ} \mathrm{C}$ should have a $\delta^{13} \mathrm{C}$ value which is about $3 \%$ o higher than the same seawater at $25^{\circ} \mathrm{C}$ [Mook et al, 1974]. However, as $\Delta^{14} \mathrm{C}$ measurements clearly show, the vertical mixing of subsurface waters is everywhere fast enough that full carbon isotopic equilibrium is never achieved, even though chemical $\left(\mathrm{CO}_{2}\right)$ equilibrium may be approached [Broecker and Peng, 1982]. Thus, while never reaching its complete expression, the magnitude of the thermodynamic isotopic effect varies not only with temperature, but also with $\mathrm{CO}_{2}$ exchange rate and surface water residence times.

One means of establishing the relative importance of gas exchange for $\delta^{13} \mathrm{C}$ (of $\Sigma \mathrm{CO}_{2}$ ) in the present ocean is to normalize measured GEOSECS $\delta^{13} \mathrm{C}$ values [from Kroopnick, 1985] to constant phosphate, a procedure which in principle eliminates all nutrient-related variability. The slope of the $\delta^{13} \mathrm{C}$ $\mathrm{PO}_{4}$ relationship is not globally uniform, but in general, for every $1 \mu \mathrm{M} / \mathrm{kg}$ increase of $\mathrm{PO}_{4}, \delta^{13} \mathrm{C}$ decreases by about $1 \%$, a dependency close to that predicted from average $C / P$ and $\delta^{13} C$ values in marine organic material [Broecker and Peng, 1982]. If nutrient cycling were the only control on $\delta^{13} \mathrm{C}$, removing this slope should produce relatively constant $\delta^{13} \mathrm{C}$ values: large spatially coherent deviations should reflect the influence of gas exchange. We used this approach previously to demonstrate that surface waters near the Antarctic Polar Front are

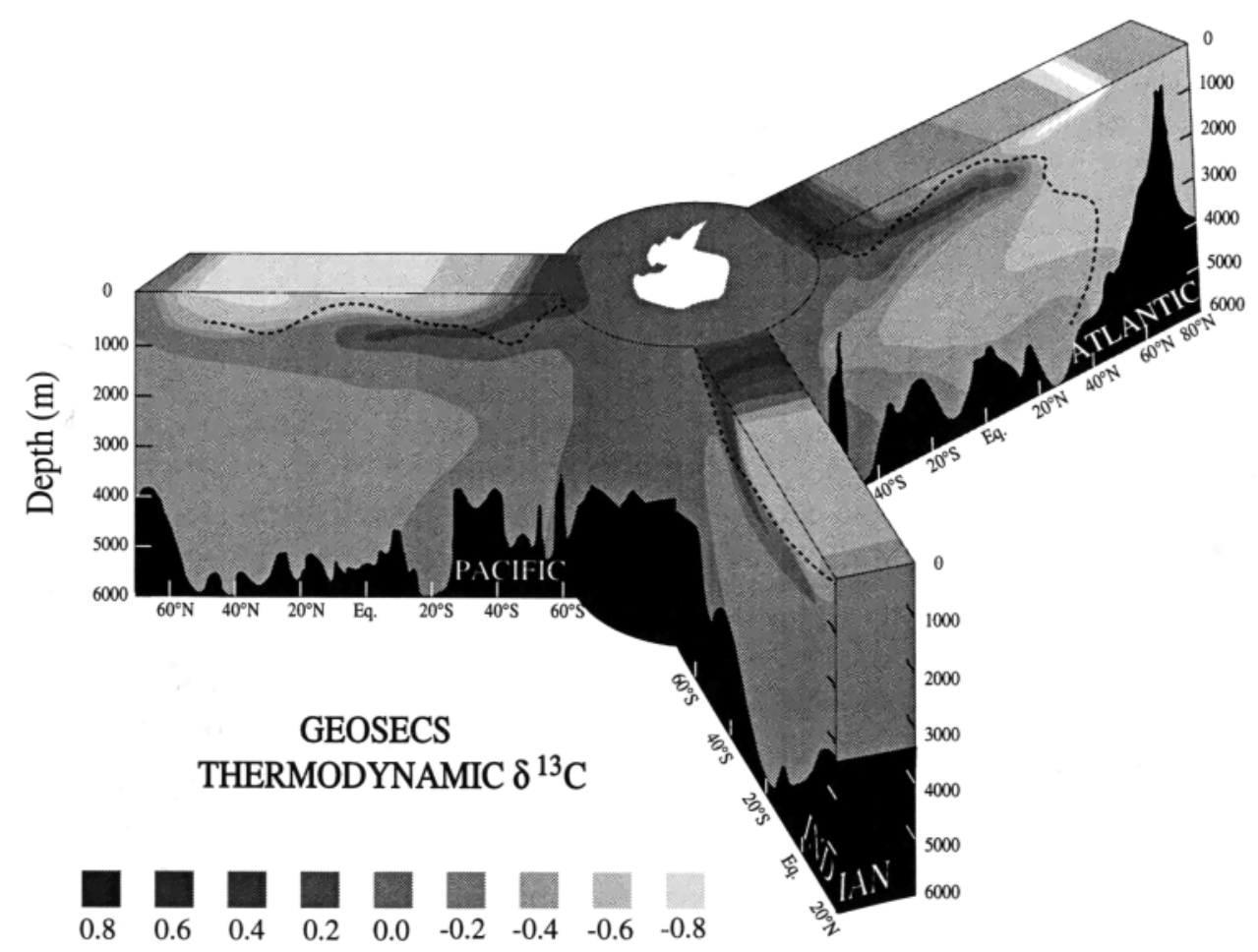

Fig. 1. GEOSECS $\delta^{13} \mathrm{C}$, normalized to constant phosphate, with the following transformation: Normalized $\delta^{13} C=\delta^{13} C+\left(0.93 \times\left[P_{4}\right]\right)-2.4$. The rationale for this normalization is given in Charles and Fairbanks [1990] and Broecker and Maier-Reimer [1992]. The latter authors use a slightly different $\delta^{13} \mathrm{C}-\mathrm{PO}_{4}$ relationship (based on a more selective analysis of the data) to make this normalization, but the results are not significantly different. This approach isolates the air-sea exchange influence. Antarctic water masses are characterized by thermodynamic enrichment (particularly in Antarctic Surface Waters and Antarctic Intermediate Water), while North Atlantic water masses show significant thermodynamic depletion. There is little variation in the deep waters of the Pacific and Indian Oceans. The contours were smoothed subjectively in the North Atlantic and North Pacific oceans, because the degree of scatter in these stations is fairly high. The dashed line shows the penetration of bomb ${ }^{14} \mathrm{C}$ at the time of the GEOSECS survey. All $\delta^{13} \mathrm{C}$ values above the line are affected to some extent by anthropogenic disturbance because fossil fuel combustion lowers the ocean-atmosphere $\delta^{13} \mathrm{C}$ [Broecker and Peng, 1982]. 
enriched in ${ }^{13} \mathrm{C}$ by as much as $1 \%$ o through air-sea exchange [Charles and Fairbanks, 1990]. Apparently, high gas exchange rates in the subantarctic zone allow partial equilibration with the atmosphere at relatively cold temperatures, in effect labelling the surface waters with relatively high $\delta^{13} \mathrm{C}$. Broecker and Maier-Reimer [1992] pointed out the same phenomenon with a similar procedure, while also comparing the effect in ocean model experiments run with different gas exchange rates.

Extending the phosphate normalization approach to GEOSECS profiles in all the ocean basins reveals some striking patterns (Figure 1). The most obvious is the tongue of thermodynamic enrichment which descends from the Antarctic Polar Front, coinciding almost perfectly with the salinity minimum which characterizes Antarctic Intermediate Water (AAIW). This distribution is what one would predict on the basis of the high Antarctic Surface Water and subantarctic values, since AAIW is derived almost entirely from these waters. The presence of this clear $\delta^{13} \mathrm{C}$ trend in all the the ocean basins demonstrates that significant thermodynamic $\delta^{13} \mathrm{C}$ effects are not limited to surface waters and must be considered at all depths, especially in water masses for which the contribution of surface waters is large. NADW is a case where the thermodynamic effect creates a relative depletion (by about $0.5 \%$ in comparison to Pacific Deep Water), presumably because the air-sea exchange in surface source waters occurs at warmer temperatures, before the cooling and sinking processes. This difference between AAIW and NADW gives rise to the especially detailed structure in normalized $\delta^{13} \mathrm{C}$ at mid-depths in the Atlantic. Even at $20^{\circ} \mathrm{N}$ in the Atlantic, the AAIW $\delta^{13} \mathrm{C}$ maximum is still well defined. As noted by Broecker and MaierReimer. [1992], Antarctic Bottom Water shows higher normalized values than Pacific Deep Water and NADW because it contains a small amount of partially equilibrated surface waters. Since no new deep water is formed in the Pacific, thermodynamic effects cannot be readily distinguished. The same applies to the deep Indian Ocean. The deep waters of these basins fall most nearly on the nutrient $-\delta^{13} \mathrm{C}$ trend line expected from biological fractionation [Broecker and Maier-Reimer, 1992].

It is important to emphasize that phosphatenormalized $\delta^{13} \mathrm{C}$ values are not the same as "preformed" $\delta^{13} \mathrm{C}$ values. Preformed $\delta^{13} \mathrm{C}$ values are perhaps best estimated by normalization to $\mathrm{AOU}$ (Apparent Oxygen Utilization) [G.P. Lohmann et al., Reassessment of the influence of temperature on the distribution of ${ }^{13} \mathrm{C}$ in the upper ocean,. submitted to Paleoceanography, 1993], since oxygen deficit is in principle a better index of in situ respiration than is phosphate [Broecker and Peng, 1982]. However, preformed $\delta^{13} \mathrm{C}$ values do not reflect a full separation of gas exchange and photosynthesis/respiration processes because in many regions (the Southern Ocean is a good example) preformed nutrients are high and therefore affect the $\delta^{13} \mathrm{C}$ values. In normalizing to constant phosphate to isolate the gas exchange component, the major assumptions we make are that nutrient properties follow constant "Redfield" proportions and that the $8^{13} \mathrm{C}$ of organic matter is constant. These assumptions are almost certainly violated to some extent in the global ocean, but even considering the possible variability would not change the most important features of Figure 1. For example, the tongue of enriched $\delta^{13} \mathrm{C}$ AAIW cannot be an artifact of the normalization, since $\mathrm{C} / \mathrm{P}$ ratios in Antarctic surface and subsurface waters are close to the expected Redfield value [Chipman and Takahashi, 1989] and the use of more locally appropriate values for $\delta^{13} \mathrm{C}$ of organic matter [Rau, et al., 1989] would actually increase phosphate-normalized $\delta^{13} \mathrm{C}$ slightly.

\section{PALEOCEANOGRAPHIC IMPLICATIONS}

\section{Deep Water}

Foraminiferal $\delta^{13} \mathrm{C}$ changes are often used to deduce past circulation patterns and intensities. This strategy relies on the assumption that the $\delta^{13} \mathrm{C}$ (nutrient) differences between "end member" water masses remain relatively constant, or at least definable, and that mixing between end members can account entirely for $\delta^{13} \mathrm{C}$ variability at a particular site through time. The thermodynamic effect could obviously interfere with this strategy if it caused end member $\delta^{13} \mathrm{C}$ variability that was not monitored. For example, if the air-sea exchange processes in the North Atlantic were to become more like those in the Southern Ocean (with partial isotopic equilibrium at colder temperatures), this change could create the illusion of lower deep water nutrients and thus stronger NADW flow. As Broecker and MaierReimer (1992) suggest, it is not likely that changes in the thermodynamic effect in deep waters would be significant enough to overprint seriously the glacialinterglacial $\delta^{13} \mathrm{C}$ signal resulting from circulation changes. After all, a change of $0.5 \%$ in ${ }^{13} \mathrm{C}$ would require a $5^{\circ} \mathrm{C}$ change in average equilibration temperature, implying a fairly radical change in deep water formation processes. Nevertheless, realization that thermodynamic "tags" on various water masses might be sensitive to climate change emphasizes the importance of capturing end member variability.

This requirement applies especially to longer time scales, since the mechanisms for deep water formation and average ocean nutrient concentrations (the relative expression of air-sea exchange obviously depends on the total range of nutrients) could have been much different. Two pertinent examples occur during the late Pliocene, when the Atlantic-Pacific $\delta^{13} \mathrm{C}$ differences were apparently higher than the modern difference by 0.2 per mil [Curry and Miller, 1989; Raymo et al., 1990], and during the Miocene, when deep-water $\delta^{13} \mathrm{C}$ differences show the opposite 
pattern, averaging one-half of the present difference [Miller and Fairbanks, 1985; Wright et al., 1991, 1992]. Relating $\delta^{13} \mathrm{C}$ strictly to nutrients, these observations imply higher average ocean nutrients and more vigorous NADW flow during the Pliocene and, conversely, lower average nutrients and weaker NADW during the Miocene. Yet one could conceive of dramatically different scenarios by allowing regionally different thermodynamic influences and their mixture throughout the ocean to change [e.g. Wright et al., 1992]. The point is not that air-sea exchange completely explains these $\delta^{13} \mathrm{C}$ anomalies, nor will it ever measurably affect mean ocean $\delta^{13} \mathrm{C}$ values; on the other hand, it represents another variable to consider which, unlike $\delta^{13} \mathrm{C}$ reservoir changes, can affect the $\delta^{13} \mathrm{C}$ gradients in the ocean.

\section{Upper Layer Water}

The immediacy of the tie between $\delta^{13} \mathrm{C}$ and nutrients from surface to intermediate depths affects several prominent paleoceanographic themes. These include (1) estimating the strength of the biological "pump" of carbon by surface-to-deep $\delta^{13} \mathrm{C}$ differences [Broecker and Peng, 1982; Shackleton et al., 1983], (2) testing hypothesized links between nutrient deepening, whole ocean alkalinity, and atmospheric $\mathrm{CO}_{2}$ using intermediate depth $\delta^{13} \mathrm{C}$ records [Boyle, 1988b], and (3) assessing the partitioning of carbon between terrestrial and oceanic reservoirs with the $\delta^{13} \mathrm{C}$ of nutrient-free surface water [Curry and Crowley, 1987; Oppo and Fairbanks, 1989].

The fact that air-sea exchange effects are so spatially heterogeneous presents a fairly serious difficulty for carbon cycle models which interpret upper layer $\delta^{13} \mathrm{C}$ signals. The reason is that, though conditions in the warm nutrient-free surface waters were probably always relatively constant, a variety of evidence suggests that the subpolar regions (where thermocline and intermediate waters communicate directly with the atmosphere) were strongly

\section{Bahamas}

$\Delta$ Temperature $^{\circ} \mathrm{C}$

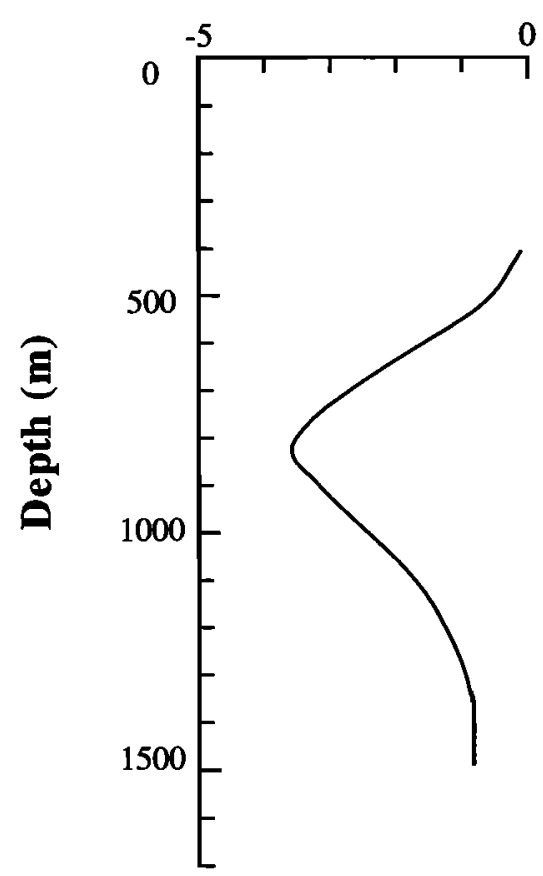

$\delta^{13} \mathrm{C} \%$ PDB

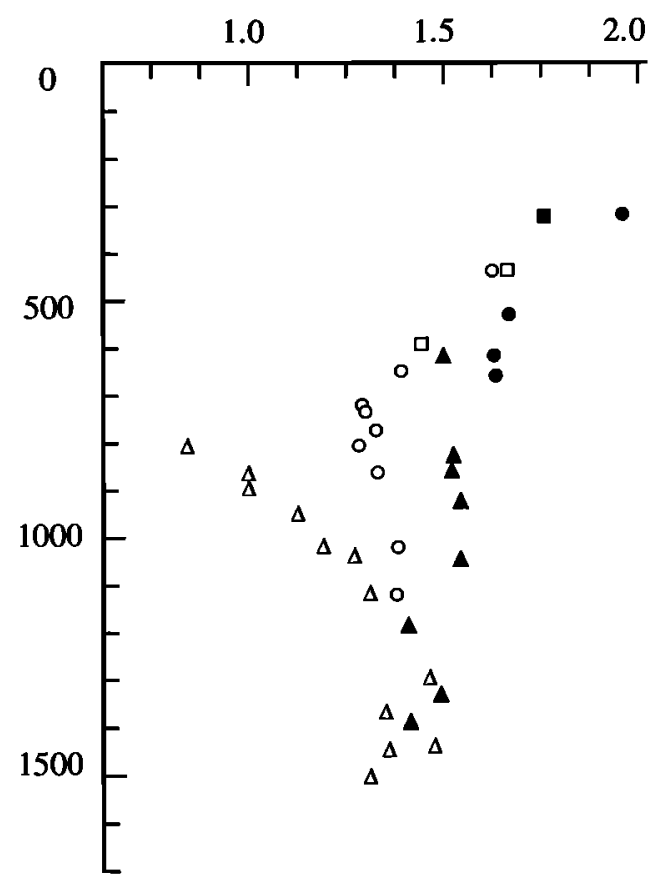

Fig. 2. Depth transect of carbon isotope values for the Holocene (open symbols) and last glacial maximum (solid symbols), taken from Slowey and Curry [1992]. The different symbol types refer to different species of benthic foraminifera. The $\Delta \mathrm{T}$ (glacial-age change in temperature is calculated here by differencing the glacial-age and Holocene $\delta^{18} \mathrm{O}$ profiles, subtracting a whole ocean change of $1.3 \%$ and multiplying the residual by -0.22 . The lack of a glacial zone of carbon isotope depletion could be related either to the removal of nutrients, or colder air-sea equilibration temperatures, or both. 
affected by Pleistocene climate change. Figure 1 shows that, at thermocline and mid-depths, there is almost a $1 \%$ difference between the thermodynamic influence on northern and southern source waters which eventually mix into the equatorial Atlantic. Thus, even subtle changes in the exchange processes occurring in these high-latitude "source" regions, or changes in the mixing of water masses with different thermodynamic tags, could account for a significant portion of the observed variability in the tropics, where the glacial-interglacial amplitude of $\delta^{13} \mathrm{C}$ records is typically a few tenths of a per mil.

Evidence for actual changes in the thermodynamic influence on these timescales is not easily determined. If temperature reconstructions for the last glacial maximum are reasonably accurate, the subpolar regions in both hemispheres cooled by $5^{\circ}$ $10^{\circ} \mathrm{C}$ [CLIMAP, 1981]. All else constant, an equivalent change in equilibration temperature (not the same as the actual temperature of the water mass) would create an intermediate-to-thermocline ${ }^{13} \mathrm{C}$ enrichment ranging from $0.5-1.0 \%$. It is unlikely that the ocean would experience such an extreme, because mixing rates, gas exchange rates, residence times and the location of water mass formation probably varied in conjunction with temperature. However, the thermodynamic change resulting from ocean cooling would be in the same direction as nutrient depletion (which has been suggested on the basis of $\mathrm{Cd} / \mathrm{Ca}$ ratios to be the prevailing condition
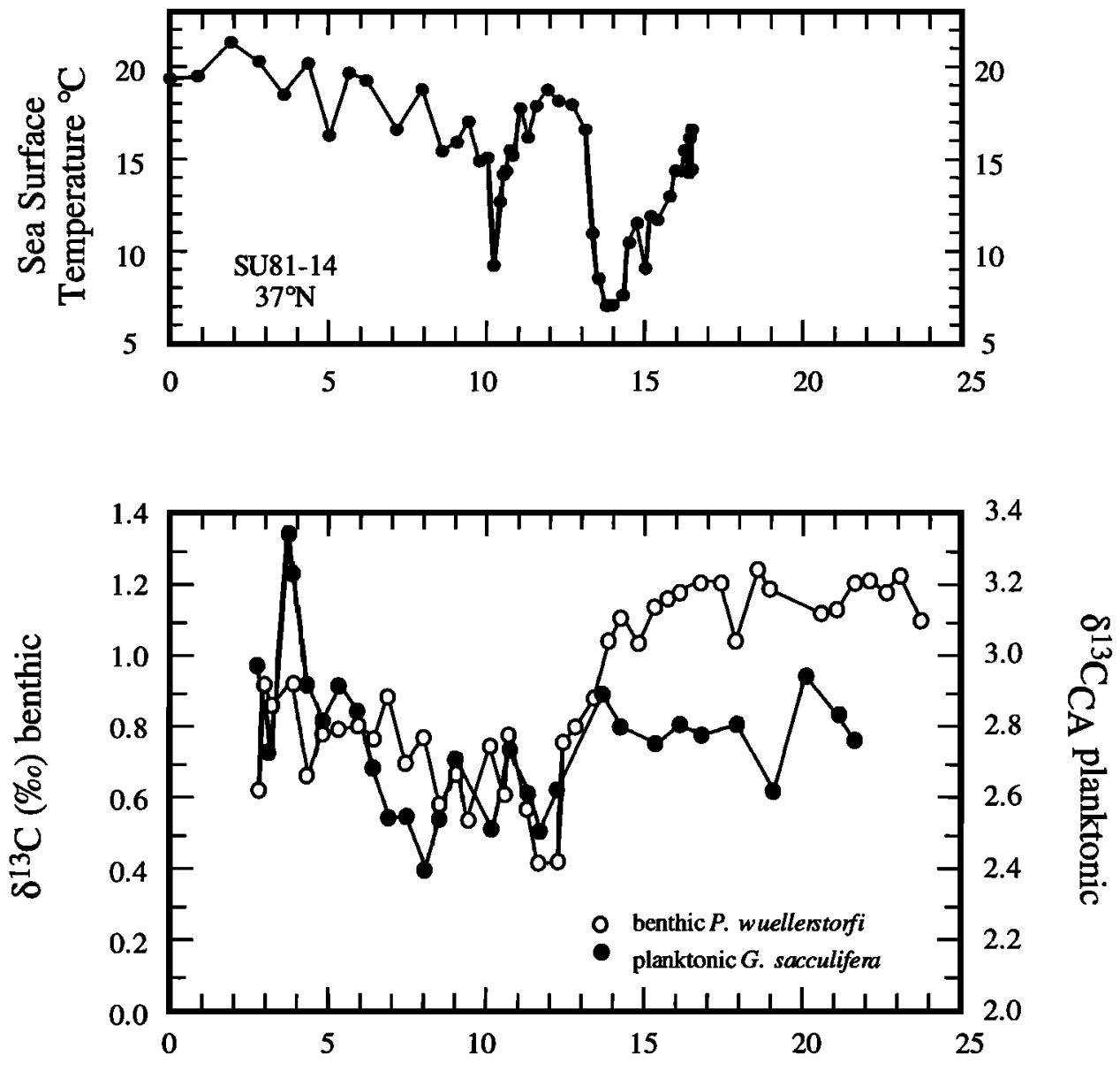

Age (kyr.)

Fig. 3. Mid-depth Atlantic $(1800 \mathrm{~m})$ carbon isotope record from the Caribbean, taken from Oppo and Fairbanks [1987], plotted along with a typical North Atlantic sea surface temperature curve for the last 25,000 years [Bard et al., 1987]. If air-sea exchange affected these carbon isotope values, one would expect anticorrelation with temperature. In general, this inverse relationship is observed, so it remains difficult to separate nutrient-related changes from thermodynamic changes without additional information. 
during glacial periods [Boyle, 1988a, 1988b]). Thus, without other supporting evidence, it is difficult to separate the nutrient and gas exchange components of upper layer $\delta^{13} \mathrm{C}$ signals, even qualitatively. $A$ recent example of this uncertainty comes from Slowey and Curry [1992], who determined isotopic ratios for the Last Glacial Maximum in a transect of cores spanning the North Atlantic thermocline. With the $\delta^{18} \mathrm{O}$ data suggesting cooler water, the glacial $\delta^{13} \mathrm{C}$ profile throughout the upper layer is consistent with nutrient depletion, thermodynamic enrichment, or both (Figure 2). Similarly, the record of mid-depth Atlantic $\boldsymbol{\delta}^{13} \mathrm{C}$ from Caribbean deep sea cores [Oppo and Fairbanks, 1987] conceivably could be interpreted as reflecting the North Atlantic Ocean temperature history (Figure 3 ), but $\mathrm{Cd} / \mathrm{Ca}$ records [Boyle and Keigwin, 1987] suggest that nutrients may have changed as well.

There are, however, two clues that the air-sea exchange $\delta^{13} \mathrm{C}$ component of the upper layer source water masses has in fact varied. The first is the planktonic $\delta^{13} \mathrm{C}$ record of the tropical Atlantic over the last 30,000 years [Curry and Crowley, 1987; Oppo and Fairbanks, 1989]. The major changes in the nutrient-free surface water record, characterized by an unexpectedly small glacial-interglacial contrast and a significant deglacial minimum, coincide almost exactly with shifts in intermediate water chemistry. No such correlation would be expected if $\delta^{13} \mathrm{C}$ was driven by nutrient variability alone and surface waters always remained nutrient free [Oppo and Fairbanks, 1989]. The second is the $\delta^{13} \mathrm{C}$ record of atmospheric $\mathrm{CO}_{2}$, which is characterized by a glacial-age decrease of $0.4-0.7 \%$ o [Marino et al., 1992; Leuenberger et al., 1992]. Barring major reductions in global ocean productivity, this large atmospheric decrease suggests increased thermodynamic fractionation, with air-sea exchange occurring at colder temperatures [Marino et al., 1992; Leuenberger et al., 1992]. This effect would be manifested preferentially in the intermediate and thermocline water masses, where the gas exchange imprint is most intense today.

The question then becomes how these apparently real thermodynamic effects may be quantified. For now, the best means for accomplishing this objective is by continuing to determine precisely the isotopic history of intermediate and thermocline source waters in conjunction with paired analyses of other nutrient tracers such as $\mathrm{Cd} / \mathrm{Ca}$. In this way, $\delta^{13} \mathrm{C}$ variations could at least be normalized to constant trace element concentrations. The North Atlantic depth transect established by Slowey and Curry [1992] and its southern hemisphere counterpart (still in the development process [J. Lynch-Stieglitz et al., unpublished manuscript, 1993] provide the ideal materials for such an analysis. One problem with this approach, however, is that trace elements are themselves often not exact proxies for other nutrients, particularly at shallow $(<400 \mathrm{~m})$ depths [Boyle, 1988a; Frew and Hunter, 1992]. Alternatively, coupled ocean-atmosphere model experiments such as those presented by Broecker and Maier-Reimer [1992] will help target the water masses most sensitive to gas exchange effects. Ultimately, the task is made easier by the fact that any hypothesized shifts in air-sea exchange effects must satisfy the constraints imposed by the atmospheric $\mathrm{CO}_{2}$ record.

\section{CONCLUSIONS}

Discriminating between the gas exchange and nutrient components of the marine $\delta^{13} \mathrm{C}$ record is of obvious importance for models of both the carbon cycle and the past oceanic circulation. The analysis of the modern ocean presented here suggests that there are major, consistent differences in the air-sea exchange effect between various water masses. These thermodynamic tags on different water masses have likely varied in the past, and therefore this source of variability, while difficult to differentiate, cannot be overlooked. Once resolved, however, the air-sea exchange component will not merely pose a complication but will add to the growing number of contraints on past ocean-climate interactions.

Acknowledgements. The authors thank E. Boyle, W. Curry and N. Slowey for constructive reviews on an earlier version of the manuscript. Discussions with W. Broecker, P. Lohmann, and J. Lynch-Stieglitz were especially valuable.

\section{REFERENCES}

Bainbridge, A. E. GEOSECS Atlantic Ocean Expedition. vol 2, Washington . C., U.S. Government Printing Office, 1980.

Bard, E., M. Arnod, J. Duprat, J. Moyes, and J.-C. Duplessy, Retreat velocity of the North Atlantic polar front during the last deglaciation determined by ${ }^{14} \mathrm{C}$ accelerator mass spectrometry, Nature, 328 , 791-794, 1987.

Boyle, E. A. Cadmium: chemical tracer of deepwater history. Paleoceanography, 3, 471-489, 1988a.

Boyle, E. A. The role of vertical chemical fractionation in controlling late Quaternary atmospheric carbon dioxide. J. Geophys. Res. 93(C12), 15701-15715, 1988b.

Boyle, E. A. and L. Keigwin, Comparison of Atlantic and Pacific paleo-chemical records for the last 215,000 years: Changes in deep ocean circulation and chemical inventories, Earth Plaent. Sci. Lett., 76, 135-150, 1985.

Boyle, E. A. and L Keigwin, North Atlantic thermohaline circulation during the past 20,000 years linked to high-latitude surface temperature, Nature 330, 35-40, 1987.

Broecker, W. S. and E. Maier-Reimer, The 
influence of air and sea exchange on the carbon isotope distribution in the sea. Global Biogeochemical Cycles, 6, 315-320, 1992.

Broecker,W.S. and T. H. Peng, Tracers in the Sea., 690 pp., Eldigio, Palisades, N.Y., 1982

Charles,C. D. and R. G. Fairbanks, Glacialinterglacial changes in the isotopic gradients of Southern Ocean surface water, in The Geologic History of Polar Oceans: Arctic vs. Antarctic, edited by U. Bleil and J. Thiede, pp. 519-538, NATO ASI Ser v. 308. Kluwer Academic, Norwell, Mass., 1990.

Chipman, D. W., and T. Takahashi, Investigation of carbon chemistry in the Weddell Sea area during the 1986 winter expedition of the F/S Polarstern: June 28, 1986-September 16, 1986, NSF technical report, Lamont-Doherty Geol. Obs., Palisades, N.Y., 1990.

CLIMAP Project Members, Seasonal reconstruction of the Earth's surface temperature at the last glacial maximum, Map and Chart Series, $M C$-36, Geological Society of America, Boulder, $\mathrm{CO}$, 1981.

Curry, W.B. and T.J. Crowley, The $\delta^{13} \mathrm{C}$ of equatorial Atlantic surface waters: Implications for Ice Age $\mathrm{pCO}_{2}$ Levels, Paleoceanography, 2, 489517, 1987.

Curry, W.B. and K.G. Miller, Oxygen and carbon isotopic variation in Pliocene benthic foraminifers of the equatorial Atlantic, Proc. ODP Sci. Results, 108, 157-166, 1989.

Duplessy, J. C., N. J. Shackleton, R. G. Fairbanks, L. Labeyrie, D. Oppo, ,and N. Kallel, Deepwater source variations during the last climatic variations and their impact on the global deep water circulation, Paleoceanography 3, 343-360, 1988.

Froelich, P. N., R. A. Mortlock, and A. Shemesh, Inorganic germanium and silica in the Indian Ocean: biological fractionation during (Ge/Si)/OPAL formation, Gobal Biogeochemical Cycles, 3, 79-88, 1989.

Frew, R.D., and K. A. Hunter, Influence of Southern Ocean waters on the cadmium phosphate properties of the global ocean, Nature, 360, 144-146, 1992.

Kroopnick, P. The distribution of carbon-13 in the world oceans, Deep Sea Res. 32: 57-84, 1985.

Lea, D. W., and E.A. Boyle, Foraminiferal reconstructions of barium distributions in water masses of the glacial ocean. Paleoceanography 5, 719-742, 1990.

Leuenberger, M., U. Siegenthaler, and C. C. Langway, Carbon isotope composition of atmospheric $\mathrm{CO}_{2}$ during the last ice age from an Antarctic ice core, Nature, 357, 488-490, 1992.

Marino, B. D., M. B, Mc Elroy, R.J. Salawich, and W.G. Spaulding, Glacial-interglacial variations in the carbon isotopic composition of atmospheric $\mathrm{CO}_{2}$, Nature 357, 461-466, 1992.

Mix, A. C., and Fairbanks, R. G., North Atlantic surface ocean control of Pleistocene deep ocean circulation, Earth Planet. Sci. Lett., 73, 231-243, 1985.

Miller, K. G. and R. G. Fairbanks, Oligocene to Miocene carbon isotope cycles and abyssal circulation changes, in The Carbon Cycle and Atmospheric $\mathrm{CO}_{2}$ : Natural Variations Archean to Present. Geophys. Monogr. Ser., vol. 32, edited by E. T. Sunquist and W. S. Broecker, pp. 469-486, AGU, Washington, D. C., 1985.

Mook, W. G., J. C. Bormmerson, and W.H. Stoverman. Carbon isotope fractionation between dissolved bicarbonate and gaseous carbon dioxide, Earth Planet. Sci. Lett., 22, 69-176, 1974.

Oppo, D.W., and R.G. Fairbanks, Variability in the deep and intermediate water circulation of the Atlantic Ocean during the past 25,000 years: Northern Hemisphere modulation of the Southern Ocean, Earth Planet. Sci. Letters, 86, 1-15, 1987.

Oppo, D. W., and R. G. Fairbanks, Carbon isotope composition of tropical surface water during the past 22,000 years, Paleoceanography, 4, 333-351, 1989.

Rau, G.H., T. Takahashi, and D.J. Des Marais, Latitudinal variations in plankton $\delta^{13} \mathrm{C}$, Implications for $\mathrm{CO}_{2}$ and productivity in past oceans, Nature, 341, 516-518, 1989.

Raymo, M. E., W. F. Ruddiman, J. Backman, B. M. Clement, and D. G. Martinson, Late Pliocene variation in northern hemisphere ice sheets and North Atlantic Deep Water circulation,

Paleoceanography, 4, 413-446, 1989.

Shackleton, N.J., Imbrie, J., and Hall, M.A., Oxygen and carbon isotope record of East Pacific core V19-30: implications for the formation of deep water in the late Pleistocene North Atlantic, Earth Planet. Sci. Lett., 65, 233-244, 1983.

Slowey, N.C. The modern and glacial thermoclines along the Bahama Banks. Ph.D. dissertation, WHOI-MIT, WHOI 90-49, 1990.

Slowey, N. C., and W.B Curry, . Enhanced ventilation of the North Atlantic subtropical gyre thermocline during the last glaciation. Nature 358 , 665-668. 1992.

Wright, J. D., K. G. Miller, and R. G. Fairbanks, Evolution of deep-water circulation: Evidence from the late Miocene Southern Ocean, Paleoceanography, 6, 275-290, 1991.

Wright, J. D, K. G. Miller, and R. G. Fairbanks, Miocene stable isotopes: Implications for deepwater circulation and climate, Paleoceanography, 7, 357-389, 1992.

C. D. Charles, Scripps Institution of Oceanography, University of California, San Diego, La Jolla, CA, 92093.

R. G. Fairbanks and J. D. Wright, Lamont-Doherty Earth Observatory, Palisades, NY 10964.

(Received February 25, 1993;

revised June 3, 1993;

accepted June 3, 1993.) 